\title{
POTENSI PROBIOTIK DALAM TATALAKSANA ORAL CANDIDIASIS: Ulasan Sistematik
}

\author{
Nuri Fitriasari*, Indah Suasani Wahyuni**
}

${ }^{\star}$ Program Pendidikan Dokter Gigi Spesialis IImu Penyakit Mulut, Fakultas Kedokteran Gigi, Universitas Padjadjaran

** Departemen IImu Penyakit Mulut, Fakultas Kedokteran Gigi, Universitas Padjadjaran, Bandung, Indonesia

Correspondence : nuri18002@mail.unpad.ac.id

Keywords:

lactobacillus, oral candidiasis, probiotic

\begin{abstract}
Background: Probiotics are living microorganisms which when given in sufficient quantities will provide health benefits to humans. The role of probiotic bacteria in the oral environment is to prevent attachment of pathogenic bacteria, produce antimicrobial substances, activate and regulate the immune response. Today probiotics are recommended for oral health maintenance and management of oral diseases, one of which is Oral Candidiasis. The purpose of this paper is to describe the potential of probiotics in the management of Oral Candidiasis.

Method: Systematic literature review used literature search methods in electronic databases: Google Scholar, Science Direct, and PubMed. The keywords were "lactobacillus", "oral candidiasis", and "probiotic". The inclusion criteria for selection of scientific articles were years of publication from 2010 to 2018; in vitro and clinical trials; published in English and full paper available. Out of 86 articles that have been screened, eleven articles have been included in this review.

Result: The articles showed the potential use of probiotics in non-clinical trials as well as clinical trial in management of oral candidiasis in various age groups, and supports the treatment with no side effects. Mechanisms of probiotic action are known to have the potential to inhibit and reduce candida spp. in the oral cavity.

Conclusion: Probiotics have the potential as antifungal agent in the prevention and therapy of oral candidiasis
\end{abstract}

\section{PENDAHULUAN}

Candida dalam bentuk yeasts merupakan konstituen normal dari flora manusia, ditemukan sebagai komensal normal pada kulit, traktus genitourinari dan gastrointestinal dan juga ditemukan di rongga mulut sekitar $25-75 \%$ individu yang sehat. Dalam keadaan tertentu candida dapat menjadi patogen oportunistik yang menyebabkan infeksi pada mukosa mulut yaitu oral candidiasis. Infeksi terutama disebabkan oleh candida albicans yang memiliki sifat dimorfik yaitu kemampuan untuk berubah bentuk menjadi blastospore ataupun hifa invasif. ${ }^{1-4}$
Candida merupakan agen paling umum yang terkait dengan oral candidiasis tanpa memandang usia. Pada anak-anak paling sering diisolasi pada permukaan gigi dan menyerang tubulus dentin serta penggunaan antibiotik jangka panjang. ${ }^{5}$ Banyak penelitian yang mengidentifikasi pada orang dewasa terjadi kolonisasi candida yang menyebabkan oral candidiasis. ${ }^{6}$ Pada usia lanjut, dengan meningkatnya harapan hidup, maka timbul permasalahan kesehatan rongga mulut seperti oral candidiasis yang umum terjadi.2,7 Oral candidiasis sering terjadi pada individu yang terlalu muda, terlalu sakit dan terlalu tua. ${ }^{7,8}$ 
Obat antifungal baik lokal maupuan sistemik telah terbukti efektif dalam mengurangi kolonisasi jamur dan mengatasi infeksi jamur, namun telah terjadi peningkatan resistensi. Resistensi terjadi karena pemakaian yang kurang adekuat, harga terlalu mahal, atau kurang patuhnya pasien terhadap perawatan sehingga diperlukan agen antijamur baru. 3,6,9,10

Dewasa ini beberapa penelitian telah dilakukan untuk mendapatkan agen antifungal yang baru, salah satunya adalah probiotik. Probiotik mikroorganisme hidup yang ketika diberikan dalam jumlah memadai akan memberikan manfaat kesehatan pada dan telah dikonsumsi selama bertahun-tahun karena alasan terapeutik dan profilaksis. ${ }^{11,12}$ Menurut World Health Organization (WHO) dan Food and Agriculture Organization (FAO), mikroorganisme hidup yang memberikan manfaat kesehatan kepada inangnya ketika digunakan dalam jumlah yang memadai disebut sebagai probiotik. ${ }^{10,12-14}$

Probiotik telah terbukti secara khusus dalam menghambat pertumbuhan patogen seperti Streptococcus mutans, bakteri kariogenik, dan candida albicans sebagai salah satu spesies candida spp., yang bertanggung jawab dalam inisiasi dan perkembangan oral candidiasis. ${ }^{2,11}$ Saat ini banyak ditemukan dalam berbagai teknik dan metode pemberian, yaitu campuran dalam makanan, kapsul, dan gel. Probiotik adalah salah satu senyawa yang tidak hanya ekonomis tetapi juga mudah didapat. Serta selain itu, penggunaannya dalam bidang farmasi dan medis telah diakui, serta tidak seperti antibiotik, probiotik tidak memiliki efek samping. ${ }^{10,15-17}$ Dalam penelitian ini kami melakukan ulasan sistematik tentang potensi probiotik dalam tatalaksana oral candidiasis.

\section{METODE PENELITIAN}

Ulasan sistematik ini mengacu pada aturan penulisan literatur yang sesuai dengan aturan Preferred Reporting Items for Systematic Reviews and Meta-Analyses (PRISMA). ${ }^{18}$

Kriteria Kelayakan:

1. Tujuan penelitian ini adalah mengetahui potensi probiotik dalam tatalaksana oral candidiasis berdasarkan artikel ilmiah yang telah dipublikasikan.

2. Kriteria artikel yang digunakan dan diulas tidak membatasi jumlah dan faktor usia sampel, metode penelitian secara in vitro dan uji klinis yang melaporkan potensi probiotik dalam tatalaksana oral candidiasis.

3. Artikel yang digunakan harus ditulis dalam bahasa Inggris dengan ketersediaan teks lengkap.

4. Publikasi selain penelitian klinis yaitu ulasan, editorial, laporan kasus, dan serial kasus serta makalah yang berfokus pada penelitian hewan tidak digunakan dalam ulasan sistematik ini.

Strategi Penelitian:

Pencarian makalah bersumber dari tiga database elektronik yaitu Google Scholar, Science Direct, dan PubMed yang dipublikasikan dari Januari 2010 sampai Mei 2018. Pencarian literatur ini dalam konfigurasi yang lebih efisien dan berfokus pada tujuan, menggunakan deskripsi Medical Subject Headings (MeSH) yaitu kata kunci untuk mengambil tema dari literatur ilmiah dengan metode Boolean, dengan kata DAN / ATAU untuk kombinasi kata kunci yang digunakan yaitu lactobacillus, oral candidiasis, probiotic. Artikel yang ditemukan dipindai dan disaring relevansinya menggunakan flowchart PRISMA. 
Pengumpulan dan Ekstraksi Data:

Petunjuk dasar pengumpulan dan ektraksi data dari PRISMA adalah PICO (Population, intervention, comparison, and outcome) kemudian disusun dalam sebuah tabel dan diagram: karakteristik penelitian (penulis pertama, judul, negara, tahun publikasi, dan kualitas literatur), karakteristik population (jumlah sampel, usia), karakteristik intervention (probiotik, candida) dan karakteristik outcome (potensial antifungal).

Penilaian Kualitias:

Kualitas artikel yang diulas, dinilai dengan menggunakan skor indeks Scopus kuartil. Artikel yang diulas ini dianggap berkualitas tinggi ketika memiliki kualitas Q1-Q4. ${ }^{19}$

\section{HASIL PENELITIAN}

1. Literatur yang ditemukan dipindai dan disaring menggunakan flowchart PRISMA seperti yang ditunjukkan pada gambar 1. Secara total, 17544 artikel yang ditemukan, terdapat 11 studi yang memenuhi kriteria kelayakan untuk ulasan sistematik. Selanjutnya karena 11 artikel tersebut 5 artikel memenuhi kualitas index scopus Q1, 5 artikel tergolong Q2 serta 1 artikel kualitas Q4.

2. Didapatkan 86 artikel setelah proses skrining eksklusi judul dan abstrak.

3. Didapatkan 34 artikel setelah skrining dari ketersediaan naskah lengkap.

4. Didapatkan 11 artikel setelah dilakukan kualitas indeks scopus.

Karakteristik Penelitian :

Semua artikel yang ditinjau adalah yang dipublikasikan antara Januari tahun 2010 sampai Mei tahun 2018, yang menggunakan metoda penelitian secara in vitro dan uji klinis. Tidak ditemukan artikel penelitian in vivo yang terkait literatur sistematik ini. Sampel dari penelitian pada artikel tersebut adalah orang dewasa, anak-anak, dan pada lansia. Enam artikel tidak menunjukan kriteria menentukan usia dari sampel. Negaranegara yang melakukan penelitian hampir meliputi seluruh benua kecuali Australia. Karakteristik penelitian seperti tampak pada Tabel 1 .

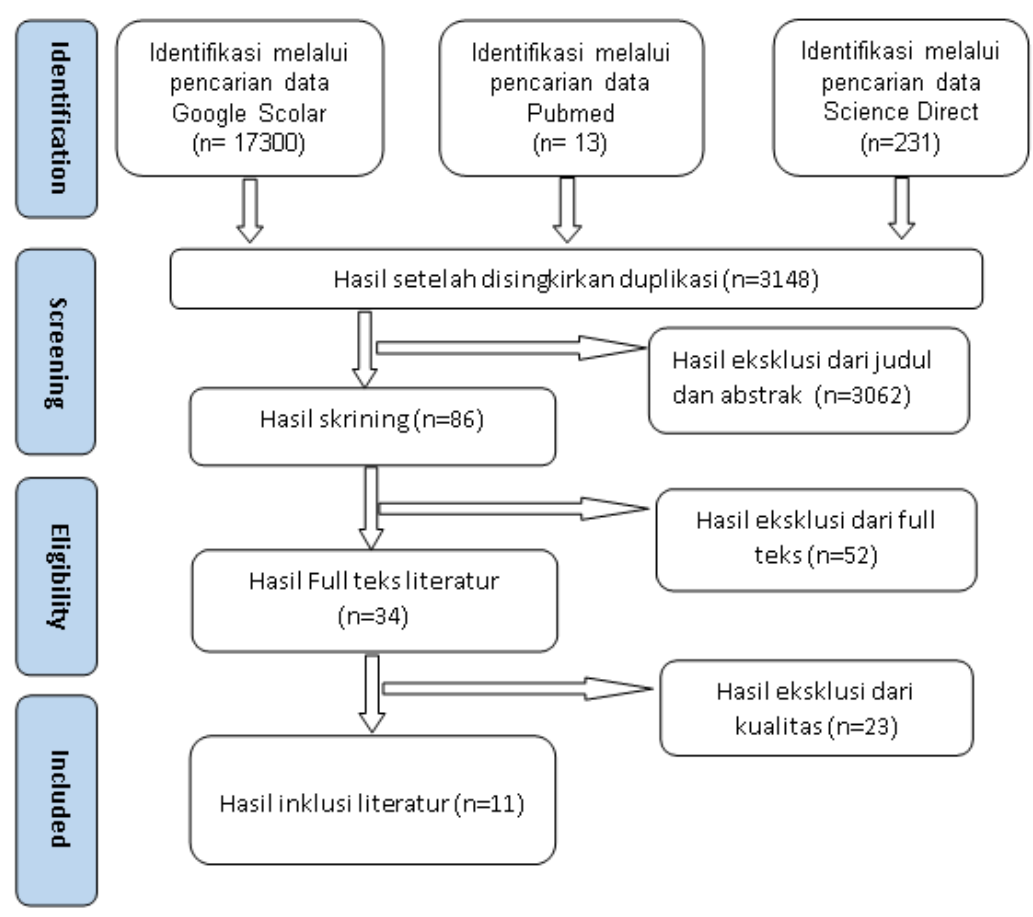


Gambar 1. Flowchart Tinjauan Sistematik Menurut PRISMA

Tabel 1. Karakteristik Penelitian

\begin{tabular}{|c|c|c|c|c|c|c|c|c|}
\hline \multirow[t]{2}{*}{ No } & \multirow[t]{2}{*}{ Penulis } & \multirow[t]{2}{*}{ Judul } & \multicolumn{2}{|c|}{ Sampel } & \multirow{2}{*}{$\begin{array}{l}\text { Metode } \\
\text { Penelitian }\end{array}$} & \multirow[t]{2}{*}{ Negara } & \multirow[t]{2}{*}{ Tahun } & \multirow{2}{*}{$\begin{array}{l}\text { Kualitas } \\
\text { Scopus }\end{array}$} \\
\hline & & & Jumlah & Usia & & & & \\
\hline 1. & $\begin{array}{l}\text { Biyari,et } \\
\text { al }\end{array}$ & $\begin{array}{l}\text { The inhibitory effect of probiotic } \\
\text { bacteria against drug-resistant } \\
\text { candida spesies isolated from the } \\
\text { oral cavity of the elderly }\end{array}$ & 72 & $\begin{array}{l}70-89 \\
\text { tahun }\end{array}$ & In vitro & Iran & 2018 & Q4 \\
\hline 2. & $\begin{array}{l}\text { Rossoni, } \\
\text { et al }\end{array}$ & $\begin{array}{l}\text { Antifungal activity of clinical } \\
\text { lactobacillus strains against } \\
\text { candida albicans biofilms : } \\
\text { identification of potensial probiotik } \\
\text { candidates to prevent oral } \\
\text { candidiasis }\end{array}$ & 41 & $\begin{array}{l}19-21 \\
\text { tahun }\end{array}$ & In vitro & $\begin{array}{l}\text { Brazil, } \\
\text { USA }\end{array}$ & 2018 & Q2 \\
\hline 3. & $\begin{array}{l}\text { Jorgense } \\
\text { n,et al }\end{array}$ & $\begin{array}{l}\text { Probiotic lactobacillus reuteri has } \\
\text { antifungal effects on oral candida } \\
\text { spesies in vitro }\end{array}$ & $\mathrm{n} / \mathrm{a}$ & $\mathrm{n} / \mathrm{a}$ & In vitro & Denmark & 2017 & Q1 \\
\hline 4. & $\begin{array}{l}\text { Song } \\
\text { Young, et } \\
\text { al }\end{array}$ & $\begin{array}{l}\text { Inhibitory effects of lactobacillus } \\
\text { rhamnosus and lactobacillus } \\
\text { casei on candida biofilm of } \\
\text { denture surface }\end{array}$ & $\mathrm{n} / \mathrm{a}$ & $\mathrm{n} / \mathrm{a}$ & In vitro & Korea & 2016 & Q1 \\
\hline 5. & $\begin{array}{l}\text { Zhao, et } \\
\text { al }\end{array}$ & $\begin{array}{l}\text { In vitro inhibitory activity of } \\
\text { probiotic products againts oral } \\
\text { candida spesies }\end{array}$ & $\mathrm{n} / \mathrm{a}$ & $\mathrm{n} / \mathrm{a}$ & In vitro & China & 2016 & Q2 \\
\hline 6. & $\begin{array}{l}\text { Jiang, et } \\
\text { al }\end{array}$ & $\begin{array}{l}\text { Interactions between lactobacillus } \\
\text { rhamosus GG and oral micro- } \\
\text { organisms in an in vitro biofilm } \\
\text { model }\end{array}$ & $\mathrm{n} / \mathrm{a}$ & $\mathrm{n} / \mathrm{a}$ & In vitro & Finland & 2016 & Q2 \\
\hline 7. & $\begin{array}{l}\text { Hasslof, } \\
\text { et al }\end{array}$ & $\begin{array}{l}\text { Growth inhibition of oral mutans } \\
\text { streptococci and candida by } \\
\text { commercial probiotic lactobacilli } \\
\text { an in vitro study }\end{array}$ & $\mathrm{n} / \mathrm{a}$ & $\mathrm{n} / \mathrm{a}$ & In vitro & Sweden & 2010 & Q1 \\
\hline 8. & $\begin{array}{l}\text { Mishra, et } \\
\text { al }\end{array}$ & $\begin{array}{l}\text { Antimicrobial efficacy of probiotic } \\
\text { and herbal oral rinses against } \\
\text { candida albicans in children: A } \\
\text { randomized clinical trail }\end{array}$ & 60 & $\begin{array}{l}6-14 \\
\text { tahun }\end{array}$ & Uji klinis & India & 2016 & Q2 \\
\hline 9. & $\begin{array}{l}\text { Ishikawa, } \\
\text { et al }\end{array}$ & $\begin{array}{l}\text { A Multispecies probiotic reduces } \\
\text { oral candida colonization in } \\
\text { denture wearers }\end{array}$ & 59 & $\mathrm{n} / \mathrm{a}$ & Uji klinis & Brazil & 2014 & Q1 \\
\hline 10. & Bodi, et al & $\begin{array}{l}\text { Effect of probiotic bacteria on oral } \\
\text { candida in frail elderly }\end{array}$ & 215 & $\begin{array}{l}60-102 \\
\text { tahun }\end{array}$ & Uji klinis & $\begin{array}{l}\text { Sweden, } \\
\text { Denmark }\end{array}$ & 2012 & Q1 \\
\hline 11. & $\begin{array}{l}\text { Mendonca } \\
\text { et al }\end{array}$ & $\begin{array}{l}\text { Effects of probiotic bacteria on } \\
\text { candida presence and IgA anti- } \\
\text { candida in the oral cavity of elderly }\end{array}$ & 42 & 65 & Uji klinis & Brazil & 2012 & Q2 \\
\hline
\end{tabular}

Keterangan: $\mathrm{n} / \mathrm{a}=$ not applicable

\section{Ringkasan Temuan Utama:}

Artikel penelitian yang ditinjau, menunjukan intervensi bakteri probiotik dan candida seperti pada tabel 2. Didapatkan hasil 8 literatur menggunakan bakteri probiotik bersumber dari produk probiotik, satu bersumber dari saliva, dua artikel tidak menyebutkan sumber probiotik. Bentuk sediaan probiotik yang paling banyak yaitu yogurt $(23 \%)^{2,10,11}$, probiotik komersial $(22 \%)^{20,21}$, permen $(11 \%)^{22}$, susu $(11 \%)^{10}$, kapsul $\operatorname{mint}(11 \%)^{6}$, tablet 
mint $(11 \%)^{3}$ dan saliva $(11 \%)^{23}$. Presentase data tersebut seperti tampak pada gambar 2 .

Jenis bakteri probiotik yang digunakan adalah 23 jenis bakteri yaitu Leuconostoc mesenteroide, Lactobacillus plantarum, Lactobacillus casei, Lactobacillus divergens, Lactococcus piscium, Lactococcus lactis, Lactococcus raffinolactis, Lactobacillus paracasei, Lactobacillus rhamnosus, Lactobacillus fermentum,
Lactobacillus reuteri, Lactobacillus acidophilus, Bifidobacterium breve, Streptococcus thermophilus, S.salivarius, Basilus Subtilis, Basilus licheniformis, enterococcus faecium, lacyobasilus bulgaricus, Streptococcus oralis kj3, streptococcus uberis kj2, streptococcus rattus jh145, dan Bifidobacterium bifidum. Presentase data untuk jenis bakteri probiotik seperti tampak pada gambar 3 .

Tabel 2. Intervensi dari Bakteri Probiotik dan Bakteri Candida

\begin{tabular}{|c|c|c|c|c|c|c|c|}
\hline \multirow[t]{3}{*}{ No } & \multirow[t]{3}{*}{ Referensi } & \multirow{3}{*}{$\begin{array}{l}\text { Metode } \\
\text { Peneliti } \\
\text { an }\end{array}$} & \multicolumn{4}{|c|}{ Intervensi } & \multirow{3}{*}{$\begin{array}{l}\text { Hasil (Potensial } \\
\text { antifungal) }\end{array}$} \\
\hline & & & \multicolumn{2}{|c|}{ Probiotik } & \multicolumn{2}{|c|}{ Candida } & \\
\hline & & & Sumber & Bakteri & Sumber & Species & \\
\hline 1 & Biyari, et al & In vitro & $\begin{array}{l}\text { Yogurt, } \\
\text { susu (sapi, } \\
\text { kerbau, } \\
\text { kambing) }\end{array}$ & $\begin{array}{l}\text { Leuconostoc } \\
\text { mesenteroide, } \\
\text { Lactobacilus } \\
\text { plantarum, } \\
\text { Lactobacilus casei, } \\
\text { Lactobacilus } \\
\text { divergens, } \\
\text { Lactococcus } \\
\text { piscium, } \\
\text { Lactococcus } \\
\text { lactis, Lactococcus } \\
\text { raffinolactis }\end{array}$ & $\begin{array}{lr}\text { Saliva } & \text { dan } \\
\text { rongga } & \text { mulut } \\
\text { lansia } & \end{array}$ & $\begin{array}{l}\text { Candida } \\
\text { albican, } \\
\text { C.glabrata, } \\
\text { C.kefyr, } \\
\text { C.tropicalis }\end{array}$ & $\begin{array}{l}\text { Leuconostoc } \\
\text { mesenteroide,L.plan } \\
\text { tarum, Lactobacilus } \\
\text { divergens memiliki } \\
\text { efek inhibisi } \\
\text { pertumbuhan } \\
\text { C.albican, } \\
\text { C.glabrata, C.kefgr, } \\
\text { C.tropicalis }\end{array}$ \\
\hline 2 & $\begin{array}{l}\text { Rossoni, et } \\
\text { al }\end{array}$ & In vitro & Saliva & $\begin{array}{l}\text { Lactobasilus } \\
\text { paracasei, } \\
\text { Lactobasilus } \\
\text { rhamnosus, } \\
\text { Lactobacilus } \\
\text { fermentum }\end{array}$ & $\begin{array}{l}\text { lesi kandidiasis } \\
\text { orofaringeal dari } \\
\text { pasien HIV- } \\
\text { positif }\end{array}$ & $\begin{array}{l}\text { Candida } \\
\text { albican }\end{array}$ & $\begin{array}{l}\text { L.paracasei, } \\
\text { L.rhamnosus, } \\
\text { L.fermentum } \\
\text { memiliki efek dalam } \\
\text { reduksi terhadap } \\
\text { jumlah candida } \\
\text { albican }\end{array}$ \\
\hline 3 & $\begin{array}{l}\text { Jorgensen, } \\
\text { et al }\end{array}$ & In vitro & $\mathrm{n} / \mathrm{a}$ & $\begin{array}{l}\text { Lactobacilus } \\
\text { reuteri }\end{array}$ & $\mathrm{n} / \mathrm{a}$ & $\begin{array}{l}\text { Candida } \\
\text { albican, } \\
\text { C.glabata, } \\
\text { C.krusei, } \\
\text { C.tropicalis, } \\
\text { C.dubliniensis, } \\
\text { C.Parapsilosis }\end{array}$ & $\begin{array}{l}\text { Lactobacilus reuteri } \\
\text { memilki efek inhibisi } \\
\text { terhadap } \\
\text { pertumbuhan } \\
\text { C.albican, C.glabata, } \\
\text { C.tropicalis, } \\
\text { C.dubliniensis, } \\
\text { C.Parapsilosis kec. } \\
\text { pada C.krusei }\end{array}$ \\
\hline 4 & $\begin{array}{l}\text { Song } \\
\text { Young, } \\
\text { et al }\end{array}$ & In vitro & $\mathrm{n} / \mathrm{a}$ & $\begin{array}{l}\text { Lactobacillus } \\
\text { acidophilus, } \\
\text { Bifidobacterium } \\
\text { breve, } \\
\text { Lactobacilus casei, } \\
\text { Lactobacilus } \\
\text { rhamnosus, } \\
\text { S.thermophilus } \\
\text { S.salivarius }\end{array}$ & $\mathrm{n} / \mathrm{a}$ & $\begin{array}{l}\text { Candida } \\
\text { albican }\end{array}$ & $\begin{array}{l}\text { Lactobacillus } \\
\text { rhamnosus, dan } \\
\text { Lactobacillus casei } \\
\text { paling efektif inhibisi } \\
\text { pertumbuhan } \\
\text { candida albican }\end{array}$ \\
\hline 5 & Zhao, et al & In vitro & $\begin{array}{l}\text { 4produk } \\
\text { probiotik } \\
\text { komersial }\end{array}$ & $\begin{array}{l}\text { Basilus Subtilis, } \\
\text { Basilus } \\
\text { licheniformis, } \\
\text { enterococcus } \\
\text { faecium, }\end{array}$ & $\begin{array}{l}\text { Pasien dengan } \\
\text { Oral Candidiasis }\end{array}$ & $\begin{array}{l}\text { Candida } \\
\text { albican, } \\
\text { Candida } \\
\text { krusei, }\end{array}$ & $\begin{array}{lr}\text { Hanya } & \text { Basilus } \\
\text { Subtilis yang } \\
\text { memiliki efek inhibisi } \\
\text { terhadap } \\
\text { pertumbuhan }\end{array}$ \\
\hline
\end{tabular}




\begin{tabular}{|c|c|c|c|c|c|c|c|}
\hline \multirow[t]{3}{*}{ No } & \multirow[t]{3}{*}{ Referensi } & \multirow{3}{*}{$\begin{array}{c}\text { Metode } \\
\text { Peneliti } \\
\text { an }\end{array}$} & \multicolumn{4}{|c|}{ Intervensi } & \multirow{3}{*}{$\begin{array}{l}\text { Hasil (Potensial } \\
\text { antifungal) }\end{array}$} \\
\hline & & & \multicolumn{2}{|c|}{ Probiotik } & \multicolumn{2}{|c|}{ Candida } & \\
\hline & & & Sumber & Bakteri & Sumber & Species & \\
\hline & & & & $\begin{array}{l}\text { Bifidobacterium, } \\
\text { lacyobasilus } \\
\text { bulgaricus, } \\
\text { streptococcus } \\
\text { thermophiles, } \\
\text { Lactobasilus } \\
\text { acidophilus }\end{array}$ & & $\begin{array}{l}\text { Candida } \\
\text { parapsilosis }\end{array}$ & $\begin{array}{l}\text { candida meskipun } \\
\text { tidak pada candida } \\
\text { krusei }\end{array}$ \\
\hline 6 & Jiang, et al & In vitro & $\begin{array}{l}\text { Produk } \\
\text { probiotik } \\
\text { komersial }\end{array}$ & $\begin{array}{l}\text { Lactabacilus } \\
\text { rhamnosus GG }\end{array}$ & $\mathrm{n} / \mathrm{a}$ & $\begin{array}{l}\text { Candida } \\
\text { albican, }\end{array}$ & $\begin{array}{l}\text { L.rhamnosus } \\
\text { memilki efek reduksi } \\
\text { terhadap jumlah } \\
\text { C. albicans }\end{array}$ \\
\hline 7 & Mishra, et al & Uji klinis & $\begin{array}{l}\text { Tablet mint } \\
\text { probiotik }\end{array}$ & $\begin{array}{ll}\begin{array}{l}\text { streptococcus } \\
\text { oralis }\end{array} & \text { kj3, } \\
\text { streptococcus } & \\
\text { uberis } & \mathrm{kj} 2, \\
\text { streptococcus } & \\
\text { rattus jh145 }\end{array}$ & $\begin{array}{l}\text { Saliva Anak } \\
\text { bebas karies gigi }\end{array}$ & $\begin{array}{l}\text { Candida } \\
\text { albican }\end{array}$ & $\begin{array}{l}\text { streptococcus oralis } \\
\text { kj3, streptococcus } \\
\text { uberis } \\
\text { streptococcus rattus } \\
\text { jh145 memiliki efek } \\
\text { reduksi terhadap } \\
\text { jumlah } \\
\text { albican }\end{array}$ \\
\hline 8 & $\begin{array}{l}\text { Ishikawa, et } \\
\text { al }\end{array}$ & Uji klinis & $\begin{array}{l}\text { Capsul } \\
\text { probiotik }\end{array}$ & Ishikawa,et al & Uji klinis & $\begin{array}{l}\text { Capsul } \\
\text { probiotik }\end{array}$ & $\begin{array}{l}\text { L. rhamnosus, L. } \\
\text { acidophilus,and B. } \\
\text { bifidu memiliki efek } \\
\text { reduksi terhadap } \\
\text { jumlah candida }\end{array}$ \\
\hline 9 & Bodi, et al & Uji klinis & $\begin{array}{l}\text { Permen } \\
\text { Probiotik }\end{array}$ & $\begin{array}{l}\text { Lactobasilus } \\
\text { reuteri }\end{array}$ & Saliva & Oral candida & $\begin{array}{l}\text { Lactobasilus reuteri } \\
\text { memiliki efek reduksi } \\
\text { terhadap jumlah oral } \\
\text { candida }\end{array}$ \\
\hline 10 & $\begin{array}{l}\text { Mendonca, } \\
\text { et al }\end{array}$ & Uji klinis & Yakult & $\begin{array}{l}\text { Lactobacilus casei, } \\
\text { Bifidobacterium } \\
\text { breve }\end{array}$ & Saliva & $\begin{array}{l}\text { Candida } \\
\text { albicans, } \\
\text { Candida } \\
\text { tropicalis, } \\
\text { Candida } \\
\text { guilliermondii } \\
\text { Candida } \\
\text { glabrata, C } \\
\text { andida } \\
\text { lipolytica } \\
\text { Candida } \\
\text { krusei, } \\
\text { Candida kefyr } \\
\text { Candida } \\
\text { parapsilosis }\end{array}$ & $\begin{array}{l}\text { Lactobacilus casei, } \\
\text { Bifidobacterium } \\
\text { breve memiliki efek } \\
\text { reduksi terhadap } \\
\text { jumlah candida }\end{array}$ \\
\hline 11 & Hasslof, et al & In vitro & $\begin{array}{l}\text { Minuman } \\
\text { probiotik, } \\
\text { yogurt, } \\
\text { permen, } \\
\text { susu } \\
\text { fermentasi }\end{array}$ & $\begin{array}{l}\text { Lactobacilus } \\
\text { plantarum, } \\
\text { Lactobacilusreuteri } \\
\text {,Lavtobacilus } \\
\text { paracasei, } \\
\text { Lactobacilus } \\
\text { rhamnosus, } \\
\text { La.acidophilus }\end{array}$ & $\mathrm{n} / \mathrm{a}$ & $\begin{array}{l}\text { Candida } \\
\text { albican }\end{array}$ & $\begin{array}{l}\text { Lactobacilus } \\
\text { plantarum, } \\
\text { Lactobacilus reuteri, } \\
\text { memiliki efek kuat } \\
\text { dalam menghambat } \\
\text { pertumbuhan } \\
\text { candida albican }\end{array}$ \\
\hline
\end{tabular}




\section{Sumber Probiotik}

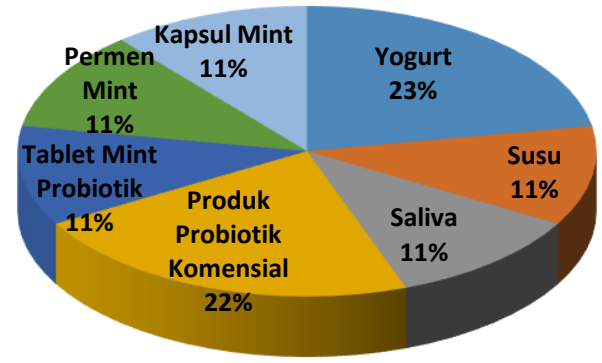

Gambar 2. Sumber Probiotik

\section{Bakteri Probiotik}

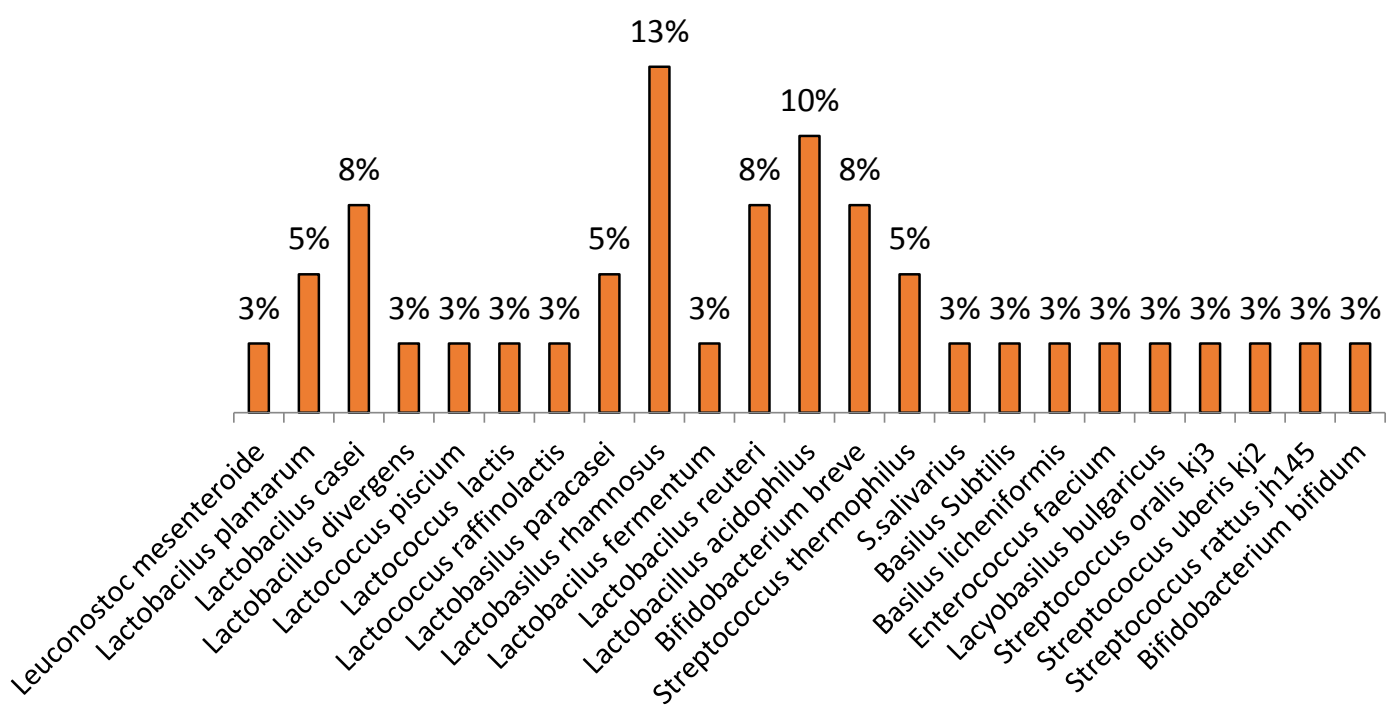

Gambar 3. Bakteri Probiotik

Sumber spesies candida yang paling banyak adalah dari saliva $(57 \%)^{2,3,10,22}$, lesi oral candidiasis $(29 \%)^{20,23}$, denture base resin $(14 \%)^{6}$, dan 4 artikel tidak menyebutkan sumbernya. Jenis spesies candida yang paling banyak adalah candida albican $(44 \%)^{1,3,10,11,20,23,24}$, candida glabrata $(11 \%)^{1,10}$, candida tropicalis $(11 \%)^{1,10}$, candida krusei $(11 \%)^{1,20}$, candida parapsilosis $(11 \%)^{1,20}$, candida kefyr $(6 \%)^{10}$, candida dubliniensi $(6 \%)^{1}$. Potensi probiotik terhadap pertumbuhan candida spp pada 11 artikel yang diteliti menunjukan bahwa dari 23 jenis bakteri probiotik yang digunakan dan yang memiliki potensi antifungal adalah 15 jenis bakteri. Lima artikel (45\%) $)^{1,10,11,20,24}$ mendeskripsikan probiotik dapat menginhibisi pertumbuhan candida spp, dan enam literatur $(55 \%)^{2,3,6,21-24}$ mendeskripsikan probiotik dapat mereduksi jumlah candida spp. Bakteri probiotik yang memiliki efek antifungal paling banyak adalah Lactobacillus rhamnosus $(19 \%)^{6,21,23,24}$, Lactobacillus reuteri $(14 \%)^{1,11,22}$ dan Lactobacillus casei $(10 \%)^{2,24}$. 
Presentase data tersebut seperti tampak pada gambar 4.

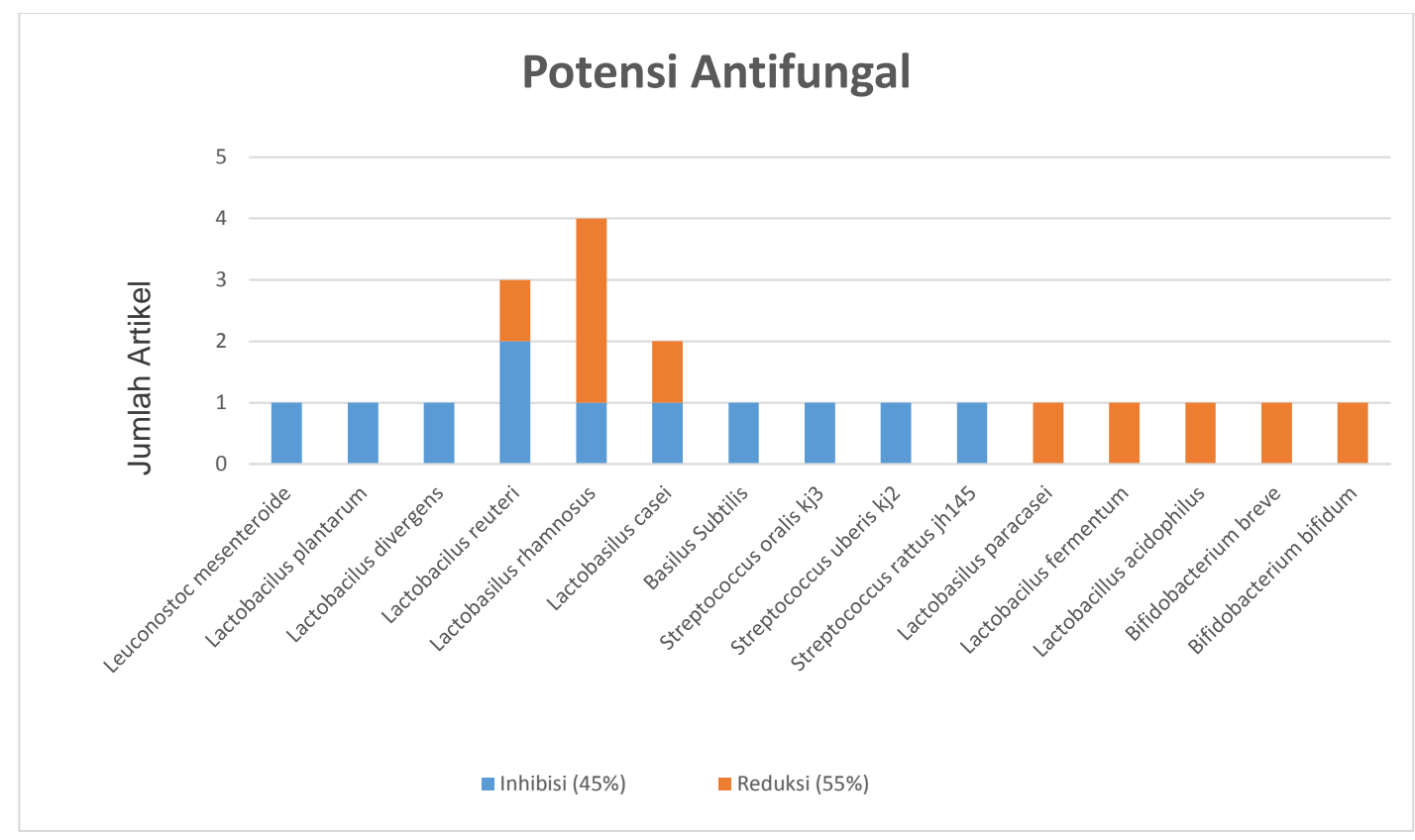

Gambar 4. Potensi Antifungal Bakteri Probiotik

\section{DISKUSI}

Beberapa spesies genus candida mampu menyebabkan candidiasis. Spesies tersebut adalah anggota flora normal di kulit, membran mukosa oral, dan saluran gastrointestinal. Candida spp, membentuk koloni di permukaan mukosa pada manusia selama atau segera setelah lahir sehingga resiko infeksi endogen senantiasa ada. Candidiasis merupakan mikosis sistemik paling umum, dan agen yang paling sering dijumpai adalah C.albican, C.tropicalis, C.parapsilosis, C.glabrata, C.guiliermondii, dan C.dubliniensis. 4,8,9,25

Oral candidiasis adalah dianggap mikosis paling umum terjadi pada manusia. Candida spp. terlibat dalam oral candidiasis dan tersebar luas di kalangan orang-orang yang berbeda di seluruh dunia. Literatur pada penelitian ini dilakukan hampir diseluruh benua kecuali di benua Australia dapat diartikan bahwa penggunaan probiotik sebagai salah satu upaya tatalaksana oral candidiasis telah dikenal merata di seluruh dunia. ${ }^{7}$

Berbeda dari mikroba lain, isolasi candida hanya dari permukaan intraoral dan tidak dapat ditafsirkan sebagai sinyal prediktif adanya suatu penyakit. Status komensal genus candida tersebut telah dievaluasi sepanjang tahun oleh beberapa peneiti, $54 \%-71,4 \%$ individu sehat dari populasi yang beragam dapat menjadi carrier candida spp. tanpa gejala apa pun. Oral candidiasis terjadi ketika beberapa kondisi predisposisi mendukung candida spp. menjadi patogen. Salah satunya karena faktor usia, sehingga terdapat pepatah medis yang mengatakan "oral thrush (syn. Pseudomembranous candidasis, moniliasis) sering terjadi pada pasien muda, sangat tua, atau sangat sakit". 7,8 Pasien muda yaitu pada bayi prematur (lahir sebelum 37 minggu) serta bayi hingga anak usia 2 tahun memiliki peningkatan risiko terjadinya oral 
candidiasis. ${ }^{5}$ Selain bayi dan anak-anak, yang termasuk dalam kelompok resiko kedua adalah para lansia. Oral candidiasis pada lansia cenderung dikarenakan kesehatan sistemik yang terganggu dan sebagian besar menggunakan gigi tiruan..$^{7,25}$

Hampir sebagian besar artikel pada penelitian ini menggunakan sampel lansia yang menggunakan gigi tiruan. Data epidemiologis menunjukkan bahwa $65-84,1 \%$ dari pemakai gigi tiruan terdapat retensi candida spp. di rongga mulut. Gigi tiruan merupakan faktor predisposisi untuk oral candidasis, permukaan akrilik dapat menjadi reservoir candida. Gigi tiruan yang rusak dan tidak beradaptasi dengan benar atau longgar dapat menyebabkan oral candidiasis terkait gesekan yang menyebabkan trauma sehingga candida dapat berkembang lebih cepat dan menjadi patogen. $7,25,26$

Faktor predisposisi baik secara sistemik ataupun lokal yang dapat menyebabkan oral candidiasis. Faktor sistemik adalah adanya gangguan pada hormonal, pisiologis, endokrin, immunologi, xerostomia, penggunaan obat, dan alkohol. Faktor lokal adalah perubahan epitel, oral hygiene yang buruk, kehilangan dimensi vertikal, penggunaan gigi tiruan yang longgar, dan merokok. ${ }^{15,26}$

Beberapa penelitian fokus menggunakan probiotik untuk tatalaksana oral candidiasis yang disebabkan oleh candida albican di rongga mulut, dan menunjukan efektif dalam mengkontrol candida dan hyposalivasi pada lansia. 17,20 Probiotik mudah didapat dengan harga ekonomis dan tidak memilki efek samping. ${ }^{10,15,16}$ Sementara penggunaan Fluconazol secara luas selama ini mencetuskan lahirnya lebih banyak spesies yang resisten terhadap azol, seperti C.krusei dan C.lusitanie.6,9,20

Penelitian dan pengunaan probiotik selanjutnya terus berkembang. Konsep penggunaan probiotik ini pertama kali diperkenalkan pada awal abad ke-20 oleh Peraih Nobel Elie Metchnikoff. ${ }^{27}$ Koloni bakteri dengan sifat-sifat yang bermanfaat bagi kesehatan adalah banyak berasal dari anggota Lactobacillus atau Bifidobacterium. Demikian juga hasil dari ulasan sistematik ini bakteri Lactobacillus dan Bifidobacterium memiliki potensi sebagai antifungal. ${ }^{13,28}$ Bakteri probiotik anggota Lactobacillus spp adalah L.acidophilus, L.rhamnosus GG, L.johnsonii, L.rhamnosus, L.gasseri, L.reuteri,L.paracasei, sedangkan anggota dari Bifidobacterium Spp. adalah B.bifidum, B.longum, B.infantis,Bifidobacterium DN-173010. S.salivarius dan W.cibaria juga dikatakan sebagai bakteri probiotik. ${ }^{13}$

Agar dapat dianggap sebagai bakteri probiotik, kriteria berikut harus dipenuhi, yaitu dapat diisolasi dari spesies yang sama sebagaimana diinginkan (replicable), dapat bertahan hidup melalui saluran pencernaan, memiliki kemampuan untuk melekat pada jaringan inang, bersifat nonpatogenik, tidak beracun, dan bebas dari efek samping signifikan lainnya, memiliki efek menguntungkan yang dapat dibuktikan pada inang, harus stabil selama penyimpanan dan cocok dengan produk yang dimaksudkan untuknya dan untuk aplikasi oral tertentu kriteria ini mungkin perlu modifikasi agar sesuai dengan ketentuan lokal. ${ }^{13}$ Beberapa mekanisme kerja probiotik yang diduga terjadi dalam rongga mulut adalah Lactobacillus berperan penting dalam menjaga keseimbangan mikroekologi di rongga mulut, terjadi Interaksi langsung dalam plak gigi, melalui keterlibatan dalam pengikatan mikroorganisme oral dengan protein (interferensi dalam pembentukan acquired pellicle), mekanisme kerja pada pembentukan plak dan ekosistemnya yang kompleks dengan cara bersaing dan mengintervensi perlekatan bakteri lain, dan atau melalui keterlibatan dalam metabolisme substrat dan produksi bahan kimia 
yang menghambat bakteri mulut. ${ }^{29}$ Kerja probiotik tidak langsung juga terjadi dengan cara memodulasi fungsi kekebalan sistemik, menimbulkan efek pada kekebalan lokal, menimbulkan efek pada mekanisme pertahanan non-imun, meregulasi permeabilitas mukosa, sebagai antioksidan dan penghasil antioksidan, serta mencegah pembentukan plak dengan menetralkan elektron bebas. ${ }^{29,30}$ Mekanisme kerja probiotik secara umum selanjutnya seperti bagan yang tampak pada gambar 5 .

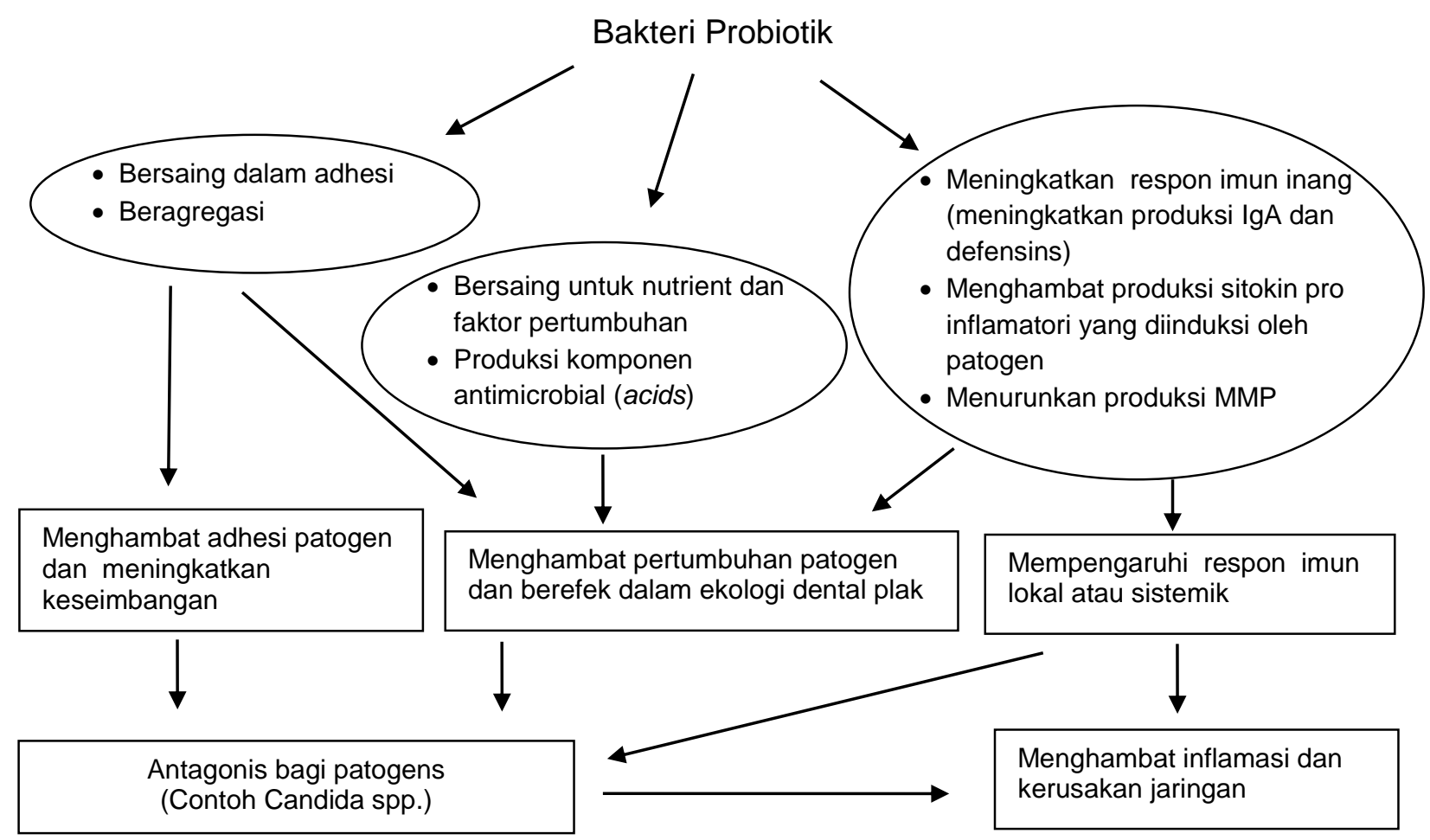

Gambar 5. Mekanisme Kerja Probiotik 29,31

\section{KESIMPULAN}

Berdasarkan ulasan sistematik ini probiotik memiliki potensi dalam pencegahan dan pengobatan tatalaksana oral candidiasis karena memilki efek antifungal, dan secara luas dapat digunakan pada seluruh tahapan usia yaitu dari bayi hingga lansia tanpa menimbulkan efek samping. Tiga jenis bakteri probiotik yang potensi paling baik adalah Lactobacillus rhamnosus, Lactobacillus reuteri, dan Lactobacillus casei.

\section{UCAPAN TERIMAKASIH}

Penulis mengucapkan terima kasih kepada RSUP Dr. Hasan Sadikin dan Program Pendidikan Dokter Gigi Spesialis (PPDGS) IImu Penyakit Mulut
(IPM) Fakultas Kedokteran Gigi (FKG) UNPAD sebagai sarana bagi klinisi untuk meningkatkan pengetahuan.

\section{DAFTAR PUSTAKA}

1. Rose M, Østrup P, Kirstine M, Jørgensen MR, Kragelund $C$, Jensen $P \varnothing$. Probiotic Lactobacillus reuteri has antifungal effects on oral Candida species in vitro. J Oral Microbiol [Internet]. 2019;9(1):1-8. Available from: http://dx.doi.org/10.1080/20002297.2016.1274 582

2. Henrique F, Pacheco B, Faria S De, Regina C, Olavo A, Jorge C. Effects of Probiotic Bacteria on Candida Presence and IgA Anti- Candida in the Oral Cavity of Elderly. 2012;23:534-8.

3. Rahul M, Shobha T, Monika R, Molay B. Antimicrobial Efficacy of Probiotic and Herbal Oral Rinses against Candida albicans in Children : A Randomized Clinical Trial. Int J Clin 
Pediatr Dent. 2016;9(11):25-30.

4. Salvatori O, Puri S, Tati S, Edgerton M. Innate Immunity and Saliva in Candida albicans mediated Oral Diseases. J Dent Res. 2016;17.

5. Mitov I. Coadministration of probiotics with antibiotics: why, when and for how long? 2012;10(4):407-9.

6. Ishikawa KH, Marcia P, Mayer A, Miyazima TY, Nakamae AEM. A Multispecies Probiotic Reduces Oral Candida Colonization in Denture Wearers. 2014;

7. Antonio E, Rosa R. Oral Candidosis. Berlin: Springer; 2015.

8. glick Michael, Chair WMF dkk. Oral Medicine. 12th ed. People'S Medical Publishing HouseUSA; 2015. 1-733 p.

9. Jawetz, Melnick, Adelberg's. Medical microbiology. 26 Edition. Vol. 317, Bmj. 2013.

10. Biyari S, Fozouni L. The Inhibitory Effect of Probiotic Bacteria against Drug - Resistant Candida Species Isolated from the Oral Cavity of the Elderly. 2018;19(6).

11. Hasslöf $P$, Hedberg M, Twetman $S$, Stecksénblicks C. Growth inhibition of oral mutans streptococci and candida by commercial probiotic lactobacilli - an in vitro study. 2010;27.

12. Audivert S, Angel M, Santos A, Carmen M, Cun $\mathrm{J}$, Sa A, et al. Isolation and characterization of probiotic strains for improving oral health. $2011 ; 7$.

13. Vestman NR. Lactobacillus characterization and effects on oral biofilm composition. Sweden: Print \& Media; 2013.

14. Stamatova M. Probiotics : Health benefits in the mouth. 2009;

15. Chanda W, Joseph TP, Wang W, Padhiar AA, Zhong M. The potential management of oral candidiasis using anti-biofilm therapies. Med Hypotheses [Internet]. 2017; Available from: http://dx.doi.org/10.1016/j.mehy.2017.06.029

16. Jain P, Sharma P. Probiotics and Their Efficacy in Improving Oral Health: A Review. 2012;2(11):151-63.

17. Hatakka K, Ahola AJ, Richardson M, Poussa T, Meurman JH, Korpela R. Probiotics Reduce the Prevalence of Oral Candida in the Elderly - a Randomized Controlled Trial. 2007;

18. Liberati A, Altman DG, Tetzlaff J, Mulrow C, Gøtzsche PC, loannidis JPA, et al. The PRISMA Statement for Reporting Systematic Reviews and Meta-Analyses of Studies That Evaluate Health Care Interventions: Explanation and Elaboration. 2009;6(7).

19. Guide QR. Scopus.

20. Zhao C, Lv X, Fu J, He C, Hua H, Yan Z. In vitro inhibitory activity of probiotic products against oral Candida species. 2016;
21. Jiang Q, Stamatova I, Kainulainen V, Korpela $\mathrm{R}$, Meurman $\mathrm{JH}$. Interactions between Lactobacillus rhamnosus GG and oral microorganisms in an in vitro biofilm model. BMC Microbiol [Internet]. 2016;1-11. Available from: http://dx.doi.org/10.1186/s12866-016-0759-7

22. Jørgensen MR, Keller MK, Kragelund C, Twetman S. Effect of Probiotic Bacteria on Oral Candida in Frail Elderly. JDR Clin Res Supl. 2012;XX(X):1-5.

23. Rossoni RD, Barros PP De, De JA, Ribeiro FDC, Velloso S, Fuchs B, et al. Antifungal activity of clinical Lactobacillus strains against Candida albicans biofilms: identification of potential probiotic candidates to prevent oral candidiasis. Biofouling [Internet]. 2018;7014:114. Available from: http://doi.org/10.1080/08927014.2018.142540 2

24. Song $Y$, Lee S. Archives of Oral Biology Inhibitory effects of Lactobacillus rhamnosus and Lactobacillus casei on Candida bio fi Im of denture surface. Arch Oral Biol [Internet]. 2017;76:1-6. Available from: http://dx.doi.org/10.1016/j.archoralbio.2016.12. 014

25. Silverman S. Essentials of Oral Medicine. London: BC Decker Inc; 2001. 170-179 p.

26. Garcia-cuesta C, Bagán J V. Current treatment of oral candidiasis: A literature review. 2014;6(5):576-82.

27. Meurman JH, Stamatova I. Probiotic applications in the oral cavity. 2007;2(1):1-8.

28. Sutula J, Coulthwaite L, Thomas L, Verran J. The effect of a commercial probiotic drink on oral microbiota in healthy complete denture wearers. 2012;1:1-10.

29. Vishnu H. Probiotik and Oral Health. oral Heal care. 2012;195-202.

30. Clancy R. Immunobiotics and the probiotic evolution. 2003;38:10-3.

31. Gomes R, Miyazak M, Jose I, Filho Z. Action of probiotics on oral pathogens: Efficacy and controversies. Dent oral Craniofacial. 2015;1(4):121-5. 